\title{
Maths in Prison
}

\author{
CATHERINE BYRNE \\ Cloverhill Prison, Ireland
}

MICHAEL CARR

Dublin Institute of Technology, Ireland

\begin{abstract}
I teach maths to all levels in an adult male remand prison in Ireland and am also studying for a PhD in maths in prison education in Dublin Institute of Technology (DIT). This paper describes recent initiatives piloted by maths teachers and school management to increase attendance, engagement and certification in maths. It assesses the effects of the initiatives and looks at future potential in this setting and in others. To set the paper in context, I begin by describing a typical day as a prison maths teacher.
\end{abstract}

\section{Key words: Prison, Education, Mathematics, Basic Skills, Literacy}

\section{"What...So What...Now What" (Rolfe 2001) "What..."}

Teaching in a prison setting is unique. Each morning in the prison school teachers wait for the students' arrival. The chatter grows as they troop in with folders under their arms, look into all the classrooms. "Where are you today?" "Where am I today?" "Check the timetable!" "Where's maths?" "You in art?" "Nearly finished my painting." Meantime teachers wait with photocopies, checking that computers and everything is set for another day. "Have I got all I need?" Checking we have pens, worksheets, folders ready, enough chairs; we wonder who will come today: who's in court, who went to the gym, who has moved prison, who was released, who is having an off day, who remembered to bring up his homework? In ones and twos and clusters they come, some chatting, some silent, walking in and out to check they are in the correct class, if not apologising and backing out, saying "See you later, I'm next door now." The mood is mostly positive, energetic and everyone wants to get going. They enter with encouraging banter to each other and to the teacher. "Let's go, let's get this done." "Did my sums last night, nothing on telly." "My cell mate helped me but he showed me, didn't do it for me."

It is group, individual, peer and collaborative learning all at once. We teachers are visitors; the cells down the corridor are their home. The group works like any group, Weight Watchers, AA, relapse prevention, or men's sheds group. Some classes go by just settling in. They may sit alone or in a group. I note that there are some friends here, some who are not so sure of themselves and some who want to work alone or move as time passes. I gesture to the cen- tral table if they want to sit together, and point to the tables around the edge if they work alone, saying pick where you want to sit, giving choices. Each one has his own folder, which they take down from the shelf. The folders all look the same; no one knows which level you are at, unless you say. First I try and see if the new men know anyone in the class, watch their response when they see who is here and who is to come. I introduce myself and say again they are very welcome, that I hope that they will come back after today but it is up to them, no pressure, saying people may like maths but not everyone does, not everyone always feels like doing it all the time.

I try and get a sense of what they did in maths as a child or adult and what brought them back to education in prison now: family, friends or some other motivation (Costelloe 2003). Some talk about this or write a few lines of maths memories, but others are less willing. I have used different methods to encourage them to reflect and share, including a maths learning history chart (Safford 2008) which is a graph where they can plot out positive and negative learning experiences. Another tool is a graph of how they see themselves compared to how others see them (Safford 2008) and they can chat to others in the class about this. These tools help the learner understand and reflect on their attitudes and experiences of maths while giving an introduction to graphs.

Often they say they need maths for a full QQI ${ }^{1}$ certificate

\footnotetext{
1 Quality Qualifications Ireland (QQI) provides certification for all education and training in Ireland other than state certificates at primary and post-primary level and the universities.
} 
or for their own personal reasons. Often they have negative memories of learning maths that they carry with them; they show you their hands shaking and sweat breaking out. Reassurance comes from their peers, the men who started a few days or weeks ago and have now settled. The chat gives strength to new entrants and words of encouragement from other prisoners have a bigger effect than any teacher's words. Soon we're all settled. It's another day.

\section{Background}

In Ireland, there have been changes in recent years in further education certification while these changes are welcome, they have provided a significant challenge for prison learners. Maths is now mandatory for accreditation for a full QQI certificate ${ }^{2}$ at all levels. Accordingly, many attending maths class would not have chosen to do the subject and only do so now to achieve a full certificate. This is a new development. Previously learners opted for subjects they liked and which made time pass because participation in education in Irish prisons is voluntary: there are no compulsory subjects. Usually subjects such as the creative arts, cookery or music are popular. This works well as these popular subjects are often gateway subjects that can lead people back to Adult Basic Education (ABE) and maths.

There is not a strong tradition of Science, Technology, Engineering or Maths (STEM) education in Irish prisons for many reasons including security, cost and history. Science equipment has risks in any setting. Space in prison education is often shared between teachers and other services so books and equipment have to be put away after class. Many prison schools are not purpose built but were adapted, which makes science and engineering more difficult to run. The number of STEM teachers working in prison is proportionally low. There are many more creative arts and ABE teachers as historically basic education (reading, writing and numeracy), creative activities (art and craft) and courses on self-esteem and life skills (yoga, parenting) have been emphasised.

However, the prison situation is not unique. There is a shortage of STEM teachers in mainstream education Ireland as many graduates go into industry. Research carried out at secondary level (Ní Ríordáin, Hannigan 2010) and adult education (Bailey 2013) found deficiencies in teacher training. ${ }^{2}$ These problems are not unique to Ireland. The UK Department of Business, Innovation Skills offers maths teachers entering Further Education (FE) cash incentives in line with their qualifications in an effort to raise standards in the sector (Sellgren 2014).

The shortage of STEM teachers causes problems in education for many reasons. Maths has to be taught in a clear way and with deep understanding so that the learner can grasp the concepts and skills. If a teacher has not got a deep understanding of maths, they cannot open the learner's eyes to

2 In mainstream schools, $50 \%$ of maths teachers are teaching out of field (Ní Ríordáin, Hannigan 2010). In adult education, $60 \%$ of maths teachers felt they did not have enough training, 5\% said they had maths anxiety, and only

8\% have a degree in maths (Bailey 2013). the beauty of maths and the hidden and untapped skills the learners possess. Understanding the applications and origins of a topic in maths helps a teacher to explain to a student. History of maths is generally not taught, so maths is being taught without any background or context. Learners need to be taught the language of maths as it is the language of business, science, and technology, as well as the language of art and music. People who are confident and able to communicate in maths are in a better position to inspire learners. Words like symmetry, $\mathrm{Pi}(\pi)$ or Fibonacci can intimidate but they describe real life concepts. This is obvious to teachers who are confident at maths but others may struggle if they are out of field.

Pythagoras theorem is a rule that can seem difficult yet is used frequently in everyday life, especially in the construction industry. Recently, in class, a prisoner was listening to the explanation of Pythagoras theorem, the famous 3 , 4,5 rule, stating that a triangle with these three sides these lengths has to have a right angle. As I was explaining that the builders of the pyramids 5000 years ago used a knotted rope and folded it into lengths of 3 and 5 and 4 knots per side, I was interrupted by a student, who said "that's just the 3-4-5 brick rule; I use that when I want to make a right angled corner when building a wall!" In short, prisoners like any other group of adults have developed invisible maths skills through life.

While everyone may not agree with Galileo's assertion that "[the universe] cannot be read until we have learnt the language and become familiar with the characters in which it is written. It is written in mathematical language, and the letters are triangles, circles and other geometrical figures, without which means it is humanly impossible to comprehend a single word", yet most will find it difficult to disagree that a learner's invisible maths skills can best be developed when the teacher sees the maths of the real world. This is why it is important to have maths teachers who have studied the subject and attended Continuing Professional Development(CPD) to keep their knowledge and communication skills up to date. This confidence helps to enable adult learners to see their skills as maths not just as common sense (Coben 2000).

Traditionally prison maths classes are small, mixed ability and have a high dropout rate. Maths is seen by many learners as hard or boring and frequently holds bad memories. Accordingly, basic maths has many of the problems of literacy, as learners may have had bad experiences with both. But it should be noted that there are significant differences also. People admit more readily to having problems with maths than with literacy, often because it is assumed that while everyone needs to write, we do not need maths as we have calculators. It is acceptable in many cultures, including Ireland, to say "I hate maths" and "I am bad at maths" as it is seen as "hard" and "head wrecking". Few are so vocal about their struggles in reading and writing.

In prison education, maths has not received the same attention as literacy. Possible reasons for this may be the pathways by which prison teachers join the service, and be- 
liefs that "literacy does not include maths" and "maths is too hard". Maths may be seen as too hard a subject for the prisoner to dip their education toe into unlike the creative subjects, which may seem an easier place to restart learning. However maths can be both a gateway subject for entry to basic education and a path to lifelong learning. And as we have seen, most people have more maths skills than they realise and can progress very fast. Maths at all levels has similar strands (e.g. Number, Data, Algebra, Shape and Measure, Problem Solving) and deep understanding at the basic level gives a strong foundation for higher levels. Adults often have acquired understanding and skills in many of these strands through life, without seeing it as maths.

While being weak at maths is acceptable, paradoxically being good at maths is also a sign of status in prison. Those attending maths are seen as "brainy" by their peers. Prisoners openly say that they are coming to maths (and other subjects) but can be shy of admitting to going to reading and writing classes. ----Maths is seen as different to basic education and this helps its status. The reasons for this are not clear. Perhaps maths is recognised as a traditional school subject, so to return to maths in prison is a sign of success. Books and materials we use in prison are generally the same as in school, which reinforces the connection to mainstream and higher education. We often use materials from maths support service websites in universities as strands like fractions and algebra are still a challenge for mainstream students at third level. This helps prisoners to see that they are doing the same topics as higher education students and this is good for status and self-esteem.

\section{"So what..."}

So, these were the many reasons why we had problems in attracting prisoners to maths class and retaining them. To address these problems several initiatives were considered.

The first was to test the men on entry to the school using the prison assessment programme for literacy and numera$\mathrm{cy}^{3}$. The grade achieved on the test was used to assign the learner to an appropriate level: either pre level, level 1, level 2 and level $3^{4}$. The grade was thus used to place the learner in a group appropriate to their ability at this time; no other analysis was done on it initially.

Another initiative I tried was to look at the breakdown of the results over the years to determine the type of questions that students found the most challenging. The results in one prison showed that those who did not finish level 3 struggled most with division, adding big numbers, decimals, bills and the 24 hour clock. This provided us with useful insight into gaps in the learners' knowledge and indicated a starting point.

Another initiative was due to the decisions by management

3 This is a test developed by Dublin prison teachers; it was designed to match the National Framework of Qualifications, (FETAC/QQI, Mapping the Learning Journey and Junior Certificate and international standards for literacy and numeracy but adapted specifically to the prison context.

4 Level 4 is the required standard for entry to third level education. and staff to increase the number of maths classes available to learners and provide full time maths classes, so another teacher switched to teaching maths. Research has shown that full time provision of maths is beneficial (Coughlan 2014), (Novitzky \& Jones 2013) which is why we decided to try it. The biggest challenge we encountered was in how to communicate effectively with each other about the students. We managed this by encouraging students to keep a brief reflective journal in their folders, for themselves and for the teachers, and we wrote a teachers' daily record of the class activities and suggestions.

So in short, classes were now grouped into level 2, 3 or 4 rather than mixed level classes as had been the case previously. Two teachers were delivering classes which meant students now had between 2 and 5 classes a week and classes were smaller. As students were blocked according to the level they reached in the assessment, they could no longer just join the group their friends were in, and some prisoners found this challenging. Another change was that all maths classes were held in the same room rather than in different rooms on different days, which gave greater stability and sense of continuity.

The most immediate lessons we learnt having introduced these initiatives included the need for good communication, as described above. Also we noted the need to communicate any changes in provision effectively to the students, as some found the change confusing at first. Another lesson we learnt was that students now took more responsibility for their own work folders and it was better to give them the full course materials from the start rather than in stages, which had been the case previously.

In order to build on progress and to coincide with national "Maths Week", we planned a week of activities with the learners to celebrate maths and connect maths education in the wider world. We decided to have an open forum on the theme "Maths and Me" and to invite students and teachers to speak for a few minutes on their experiences of learning maths and of maths in real life. Some teachers and prisoners did not relate happy experiences while others did. It gave great insight to hear the students talk in public about their learning experiences of maths. The event concluded with a "Maths Week Quiz". Several non-maths teachers (art, ESOL, literacy) contributed to the planning of the event brought their classes along to the event. A visiting Australian speaker, Matt Parker ${ }^{6}$, from the national Maths Week programme, came in to give a session with representatives from Maths Week Ireland and Waterford Institute of Technology. Maths teachers from other prison schools were invited in as observers, so their feedback would help us evaluate our new initiatives.

Prisoners helped each other to plan their speeches and they publicised the event. In order to make the event open to all prisoners, we also invited those who do not attend school.

5 See www.mathsweek.ie for further details.

${ }^{6}$ See http://standupmaths.com/ for further details 


\section{"Now What..."}

The Maths Week activity helped us to connect with a national event taking place in mainstream schools and colleges. It also helped break up the routine of everyday classes and generated 'a buzz' around maths learning. It was particularly effective in developing a community of practice with staff locally and from the wider prison education community. Visiting teachers noted the prisoners' confidence in speaking about their maths learning. In prison education, high turnover means that monitoring has to be instant and having a colleague as an observer helped. The best evaluations are often informal and the prison learners also contributed to the evaluation, saying things like - "I am remembering what I did not know I knew" and "time flew". Initial feedback showed that they enjoyed people talking about their maths stories and the learning and fun in the quiz. Teachers have subsequently run maths events in another prison centre and discussed future collaboration between centres.

\section{Reflecting on what enables learning in maths class:}

A teacher in prison has to expect the unexpected. My learning is to never assume that there is nothing left to learn. Negativity and frustration in prison education can be a challenge. Remembering the successes helps; the times when a student gets it, when he turns and teaches another, when he can talk about what he has learnt and how he learnt it. In retracing these learning steps, a learner can log what works for him, and share insights with both teacher and peers. For example, he can say what helped him to engage in maths in the beginning and along the learning journey: persistence or stubbornness when he felt like giving up in the early stages, or another learner in class showing empathy from his own experience, or taking a break from the classes when the frustration of learning or personal issues affect concentration. Adult learners, in prison and elsewhere, may need to tell the story of their past learning experiences again and again, until that story is replaced by a new one, until they can turn to the man beside them and say that he was like that, he couldn't do it and now he can... and here's how.

As a prison teacher you can organise groups, but they still change daily. Some learn faster, moods can vary, and there are bad days and good days. When someone who has struggled with fractions for days finally gets it, the joy is felt by everyone. Sometimes those who have never been to school or who left very young are easier to teach as they do not have the layers of memories of bad maths classes. Many come once and just leave after a few minutes. I wonder about them; sometimes they come back and say it was all too much now and they will try again. My hope is to learn to spot them before they disappear, or to at least try to make the few minutes they spend in class positive.

I need to remember that in prison education everything can change and nothing changes. The men who come into the classroom as angry as the day they left school (at themselves and the people they knew then) will turn around one day, if we are lucky, and say, "I never thought I could learn that". Transformation can happen and it is not instant. A new learning challenge or something outside of class happens and the anger is back just like the first day of class. What changes is that over time they may start to manage the anger, to ask for a book or a puzzle or a page of easy adding sums, or go to art or music for a little while, and then try again instead of walking away.

Without further analysis it would be unwise to suggest that the new initiatives alone can bring about such significant and important changes in attitude and self-awareness. However, I can say that they have helped to make maths learning more visible; there is now more time and staff allocated to maths, there is more awareness among both the learners and teachers, and more people are talking about it. As a result, more prisoners are considering and taking maths classes. This is helped in no small part by existing learners acting as maths ambassadors, sharing their experiences through word of mouth, encouraging others to join. As a maths teacher, the future is looking bright; to infinity and beyond.

\section{References}

Bailey, I. (2013). Doing the Maths: The training needs of numeracy tutors in Ireland 2013 and beyond. National Adult Literacy Agency (NALA). Retrieved from https:// www.nala.ie/sites/default/files/publications/doing the maths_-_the_training_needs_of_numeracy_tutors_in_ire land_2013_and_beyond.pdf.

Coben, D. (2000). Mathematics or common sense? Researching "invisible" mathematics through adult mathematics life histories. In D. Coben, J. O’Donoghue \& G.E. FitzSimons (Eds.). Perspectives on adults learning mathematics: Research and practice. Dordrecht: Kluwer Academic Publishers.

Costelloe, A. (2003). Third Level Education In Irish Prisons: Who Participates And Why (Unpublished doctoral disseration). The Open University, Milton Keynes.

Coughlan, S. (2014). " Homeless sign up for Recovery College." BBC News education. Retrieved from http:// www.bbc.com/news/education-21236680.

Novitzky, J., and Jones, E., (2013) Intensive English and maths provision in prisons; Evaluation report of pilots. Retrieved from http://www.niace.org.uk/documents/of fender-learning/Intensive-English-and-maths-pilot-in-prisons-final-report-February-2013.pdf.Rolfe, G., Freshwater, D. and Jasper, M. (2001). Critical Reflection in Nursing and the Helping Professions: a User's Guide. Basingstoke: Palgrave Macmillan.

Safford-Ramus, Katherine (2008): Unlatching the Gate - Helping Adult Students Learn Mathematics. Xlibris Corporation

Sellgren, K. (2014) "Maths Teacher Boost For Further Education Colleges." BBC News education. Retrieved from http://www.bbc.com/news/education-26035299. 
Catherine Byrne is studying for a PhD in Teaching and Learning Mathematics in prison. She also teaches Mathematics in a prison school. 